\title{
A HAJLÉKTALANSÁG LÁTHATATLAN ARCA: A LELKI OTTHON ÉS A LELKI OTTHONTALANSÁG
}

\author{
KÁNTOR ÁRPÁD ${ }^{1}$ - DÚLL ANDREA² \\ ${ }^{1}$ Eötvös Loránd Tudományegyetem \\ Pszichológiai Doktori Iskola \\ ${ }^{2}$ Eötvös Loránd Tudományegyetem Pszichológiai Intézet \\ E-mail: knarpad@yahoo.com
}

Beérkezett: 2018. március 28. - Elfogadva: 2018. november 7.

\begin{abstract}
A hajléktalanság kutatásának rö̀id történeti áttekintése után megközelitésünk alapfogalmait ismertetjük. Utána bemutatjuk a hajléktalanság pszichológiai megértését szolgáló legismertebb modelleket. Majd a kevésbé ismert „lelki otthon” és „lelki otthontalanság” jelenségének szakirodalmát összegezzük, és ismertetjük $a$ „lelki otthontalanság - lelki otthonosság kontinuum” elméletét, mely az otthontalanság fizikai és lelki aspektusainak együttes megragadására hivatott, és az alábbi tételekben foglalható össze: 1 . A „lelki otthon”, az „otthonunk” bennünk élō ideája (Kennedy, 2014), az a létfontosságú pszichés struktúra, mely meghatározza, hogy valaki hogyan él a világban és milyen érzelmei, attitüdjei stb. vannak a szociofizikai környezetével kapcsolatban. 2. A lelki otthon kialakulása és az, hogy valaki milyen körülmények közt érzi otthon magát, a saját otthonával kapcsolatos gyermekkori tapasztalataiban gyökerezik, abban, hogy milyen szociofizikai környezetben tanult meg otthonosan mozogni. Amennyiben az otthon ideája már a gyermekkorban maladaptívan alakul ki vagy a késôbbiekben sérül, akkor az érintett többé-kevésbé lelkileg otthontalanná válik, és nehézsége lesz azzal, hogy a világban, társadalomban, kapcsolataiban otthon érezze magát, illetve egy otthonteremtésre alkalmas fizikai helyhez olyan módon kötôdjön, hogy kötôdése valóban egy fizikai otthon kialakitásának alapját jelentse. 3. Nem minden fizikailag otthontalan ember lelkileg otthontalan, és nem minden lelkileg otthontalan ember válik fizikailag otthontalanná. 4. A teljes otthontalanság és a teljes otthonosság egy kontinuum két végpontja, melyek közt köztes állapotok helyezkednek el. Ez fizikai és lelki szinten egyaránt érvényes. 5. A fizikai és a lelki otthontalanság esetén egyaránt fontos különbséget tennünk a krónikus, szituatív és epizodikus otthontalanság közt. Az elmélet figyelembevétele a hajléktalanság elméleti megközelitése és a gyakorlati beavatkozások tekintetében egyaránt jelentôs lehet.
\end{abstract}

Kulcsszavak: hajléktalanság, a hajléktalanság pszichológiája, lelki otthon, lelki otthonosság, lelki otthontalanság, környezetpszichológia 


\section{BEVEZETÉS}

A hajléktalanság jelensége egyidôs az emberi közösségekkel. Társadalmainkban mindig is elôfordultak koldusok, vándorok, csavargók, illetve különbözô okokból a társadalmi „fơvonalból” kiszorult és helyüket vesztett emberek (Kántor, 2005a). A hajléktalanság azon tömeges formáját, mely a nyugati világban napjainkban megfigyelhetô, „új hajléktalanság”-ként szokták emlegetni (Marsh és Kennett, 1999). Kialakulásáért pedig a modern társadalmakban elsôsorban a teljes foglalkoztatottság végét, a jóléti biztonsági háló meggyengülését, a jóléti állam piacosodását és hiányosságait teszik felelôssé. Magyarországon a rendszerváltást követően jelent meg a hajléktalanság „új hajléktalanság” kategóriájába sorolható formája (a magyarországi hajléktalan helyzettel és a hajléktalanság magyarországi történetével számos kiváló munka foglalkozik, lásd például Gyóri, 1990, 2008; Iványi, 1997; Bényei, Gurály, Győri és Mezei, 2000; Udvarhelyi, 2014). A hajléktalanság tudományos kutatása különbözô korszakokat élt meg (Busch-Geertsema, Edgar, O’Sullivan és Pleace, 2010). A korai kutatások (az 1970-es évekig bezáróan) elsôsorban észak-amerikai és brit kutatások voltak, és a hajléktalan ember jellemzőire összpontosítottak. Ez a megközelítés túlnyomórészt figyelmen kívül hagyta a hajléktalanná váló emberre ható tágabb strukturális (pl. drasztikus társadalmi változások, megfizethetô lakhatás hiánya, gyenge szociális háló), intézményi (pl. hospitalizáció, hiányos intézményi ellátás, oktatási rendszer hiányosságai) és társas környezetet (pl. az adott társas kultúra megtartó ereje, családon belüli erôszak elterjedtsége), és abba a csapdába esett, hogy a hajléktalanná válást elsôdlegesen a hajléktalanná váló ember önhibájának tekintette - azt feltételezve, hogy a hajléktalan ember döntôen saját személyes jellemzőinek (fogyatékosság, elmebetegség, patológiás személyiség, alacsony iskolázottság) köszönheti azt, hogy az utcára került.

A 80-as években a hajléktalan élethelyzetben levô emberek számának növekedésével egyre tarthatatlanabbá vált a kizárólag önhibával magyarázó szemléletmód. Az egész társadalmat érintô, markáns változások (pl. rendszerváltások) hatására tömegek váltak hajléktalanná, és nyilvánvalóvá vált, hogy ennyi ember egyidejú hajléktalanná válásáért strukturális tényezók is felelősek, így például a munkaerópiac, a lakáspiac, az extrém szegénységben élôk aránya a társadalmon belül és a szociális ellátórendszer milyensége.

A 90-es évekre a hajléktalanságot már elsôsorban a szegénység és a marginalizáció extrém formájának tekintették (Study Group on Homelessness, 1993, 44). Felismerték, hogy a jóléti állam szerkezeti átalakulása tömegesen növelte a hajléktalanná válás kockázatát (pl. Marsh és Kennett, 1999).

Napjaink legelterjedtebb álláspontját „új ortodoxiaként” (Pleace, 2000) szokták emlegetni. Eszerint a strukturális faktorok adják a hajléktalanság táptalaját, és a súlyos személyes problémákkal küzdô emberek sokkal védtelenebbek a szociális és gazdasági trendekre, mint mások (Fitzpatrick, 2005). Más szavakkal, egy adott ország, régió, város strukturális jellemzőin (jövedelmi viszonyok, szociális háló, egészségügyi ellátó rendszer stb.) múlik, hogy ott mennyire nehéz vagy épp könnyú „nemhajléktalannak” lenni, míg személyes problémákon múlik, hogy az adott körülmények között meg tudjuk-e tartani magunkat a „nemhajléktalan” létben. 
A jelenlegi tudásunk szerint a hajléktalanság tehát strukturális (alacsony jövedelem, megfizethetô lakhatás hiánya, szociális védelem hiányosságai), intézményi (nehezen elérhetố intézményi ellátás, hospitalizáció), kapcsolati (kapcsolati konfliktusok, családon belüli erôszak, a szülôi házból való túl korai kikerülés) és személyes tényezốk (pszichiátriai betegség, addikció, elhúzódó betegség, fogyatékosság, alacsony iskolai végzettség) komplex összjátékának eredménye (Busch-Geertsema és mtsai, 2010; Bényei és mtsai, 2000).

Annak ellenére, hogy a hajléktalansággal foglalkozó szakmákban elméleti konszenzus van a személyes tényezôk fontosságáról, a hajléktalanság intrapszichés vonatkozásainak kutatása meglehetôsen elhanyagolt. Elképzelhetô, hogy ennek a hiányosságnak az az oka (lásd pl. Bényei és mtsai, 2000), hogy a kutatók többsége (a jelen tanulmány szerzóit is beleértve) tart attól, hogy amennyiben a figyelem újra a hajléktalan ember intrapszichés világára irányul, felerôsödik a hajléktalan emberek hibáztatásának a korai kutatások kapcsán már említett trendje.

Az eddigi kutatások hozadékából tanulva a hajléktalan élethelyzetben éló ember és a hajléktalanság jelenségének vizsgálata során fontos törekednünk annak elkerülésére, hogy a hajléktalan embereket tehetetlen áldozatoknak állítsuk be, akik óket meghaladó erôk passzív elszenvedôi, ugyanakkor fontos elkerülnünk azt is, hogy a hajléktalan embert patologizáljuk vagy kriminalizáljuk, azt képviselve, hogy kizárólag ó tehet a hajléktalanságáról (Cloke, May és Johnsen, 2010). Meggyózôdésünk, hogy a hajléktalanság intrapszichés és interperszonális pszichológiája kelló óvatosság mellett feltárható és a strukturális tényezôk kontextusában a prevenció szolgálatába állítható anélkül, hogy belesétálnánk a fenti két csapda („a hajléktalan ember: tehetetlen áldozat” vagy „a hajléktalan ember: egyedüli felelős, bűnös”) valamelyikébe.

\section{A JELEN TANULMÁNY KULCSFOGALMAI}

A jelenséget, melynek elnevezésére a jelenlegi magyar köznyelvben (és ezzel összhangban cikkünk bevezetésében is) leginkább a „hajléktalanság” kifejezést használjuk, az idôk során számtalan néven nevezték. Az elmúlt évtizedek magyar szóhasználatát véve azt láthatjuk, hogy a jelenség teljes tagadásától, a pejoratív elnevezéseken át (például közveszélyes munkakerülő, csöves, csavargó) jutottunk el a szakmaibb „hajléktalan”, majd a sokkal humánusabb „hajléktalan ember” kifejezéshez (mely már a szerep mögötti embert is láttatja). A hajléktalan szó (ami a lakhatás hiányát emeli ki) gyújtôfogalommá vált, mely a rendszerváltás után segítette a kitaszítottakon segítô ellátórendszer kialakítását és egységes érdekképviseletét, ugyanakkor el is fedte azt a komplexitást, amivel a hajléktalan ellátás gyakorlatában dolgozók nap mint nap találkoznak (Bényei és mtsai, 2000).

A hajléktalanság kutatásához és hatékony prevenciós programok kidolgozásához azonban sokkal precízebb és árnyaltabb szóhasználatot kínáló modellek is kidolgozásra kerültek. Ezek közül jelen megközelítés szempontjából kettôt tartunk mérvadónak: egyrészt az ETHOS-t (European Typology of Homelessness and Housing Exclusion „az otthontalanság és a lakhatásból való kirekesztettség európai tipológiája”), melyet a hajléktalansággal foglalkozó szakma egyre szélesebb körben használ (Edgar, 2009; 
Busch-Geertsema és mtsai, 2010; Amore, Baker és Howden-Chapman, 2011), másrészt a Bényei és munkatársai (2000) által kidolgozott és magyar viszonylatban elterjedt modelljét.

Az ETHOS három dimenziót (fizikai, szociális és jogi) határoz meg. Ebben a megközelítésben akkor beszélhetünk hajléktalanságról, ha ezek mentén - bármilyen kombinációban - kirekesztôdik valaki. A három dimenzióban megjelenố hiányok alapján az otthon négyféle hiányáról beszélhetünk: „fedélnélküliségrôl”, „lakástalanságról”, „bizonytalan lakáshelyzetről” és „elégtelen lakáskörülményrôl”. Az ETHOS ezeket a fogalmi kategóriákat 13 gyakorlati kategóriára osztja, melyekbe a hajléktalan emberek élethelyzetük, illetve lakhatási helyzetük alapján besorolhatók (lásd bôvebben Busch-Geertsema és mtsai, 2010).

Szempontunkból ennek a definíciónak fontos értéke, hogy a jelenség fizikai és jogi oldala mellett nyíltan számol a hajléktalanság szociális dimenziójával is. Ugyanakkor figyelmen kívül hagyja a pszichológiai dimenziót. Az ETHOS nem számol például azzal, hogy az adott megfelelőnek tekintett hely találkozik-e az egyén vagy család otthonképével, az érintett ember igényeivel (milyen körülmények közt otthonos), szükségleteivel, ahogy egyéb olyan tényezôkkel sem, mint például az érintett öndefiníciója (pl. hajléktalannak éli-e meg magát).

Bényei és munkatársai (2000) modellje a hajléktalanság különbözó fokozatait négy kategóriába sorolja. Ezek közül az elsô, legszúkebb kategória a „fedél nélkülieké”. A fedél nélküli élethelyzetben azok az emberek vannak, akik éjszakáikat közterületen, a szabad ég alatt vagy valamely nem lakhatást szolgáló zugban töltik. A második, tágabb kategóriába az effektív hajléktalan emberek tartoznak. Effektív hajléktalanoknak tekinthetôk azok, akik „fedél nélküliek”, és mellettük azok is, akik semmilyen stabil lakhatási lehetôsséggel nem rendelkeznek, akik nap mint nap meg kell küzdjenek azért, hogy éjszaka valahol (pl. hajléktalanellátó intézményekben) alhassanak. A harmadik, még tágabb kategória a „lakástalanoké”. Lakástalannak számítanak azok, aki fedél nélküliek, vagy effektív hajléktalanságban élôk, vagy stabilan nem lakásban, de lakhatást szolgáló helyiségben lakók (pl. munkásszállók, börtönök, bentlakásos intézmények lakói), vagy tartósan lakásban töltik éjszakájukat, de a lakás folyamatos használata fölött nem rendelkeznek (pl. albérlók, ágybérlók, szívességi lakáshasználók, befogadottak, felnôtt családtagok). Végül a negyedik, legtágabb kategória az „otthontalanok” kategóriája. Otthontalan emberek (nemzetközi terminológiával: „homeless”, ennek a fogalomnak a szinonimája „a hajléktalanság veszélyében élook”), akik „fedél nélküliek”, vagy effektív hajléktalan vagy lakástalan helyzetben élook, vagy lakásban lakók, akiknek lakása alkalmatlan (pl. túlzsúfolt vagy nagyon alacsony fizikai színvonalú) arra, hogy benne családot alapítsanak és otthont rendezzenek be.

Bényei és munkatársai megközelítésében az elsô három definiált kategória kizárólag a lakhatás fizikai dimenziójával operál, és a negyedikben is expliciten csak a szociális dimenzió jelenik meg a fizikai mellett. A pszichológiai dimenziót csak sejteni lehet az „alkalmatlan” kifejezés mögött.

A továbbiakban a fenti két modellból hiányolt pszichológiai dimenzióval fogunk foglalkozni. Bemutatjuk a már létezó pszichológiai megközelítéseket, majd külön ismeretjük a „lelki otthon” („lelki otthonosság”) és a „lelki otthontalanság” koncepcióját, mely 
véleményünk szerint alkalmas arra, hogy a pszichológiai dimenzió egy fontos aspektusát megragadhatóbbá, kutathatóvá és a fenti két modellhez illeszthetôvé tegyük.

A lelki otthon (psychic home) alatt a Kennedy (2014) által leírt létfontosságú pszichés struktúrát értjük, mely alapvetôen meghatározza azt, hogy valaki hogyan érzi magát, hogyan él a világban és milyen érzelmei, attitûdjei, előfeltevései vannak az ôt körülvevố szúkebb és tágabb szociofizikai környezettel kapcsolatban. Arról szól, hogy milyen a bennünk élô otthon ideája, mit jelent számunkra az otthon, milyen fizikai, szociális, érzelmi légkört, milyen hangulatot, milyen társas dinamikát. Milyen az a közeg, amelyben otthonosan mozgunk, amelyben otthon érezzük magunkat? A lelkileg otthonos ember egészséges „gyökerekkel” rendelkezik, amelynek köszönhetôen képes otthon érezni magát a világban, társadalomban, kapcsolataiban, illetve egy otthonteremtésre alkalmas fizikai helyhez olyan módon képes kötôdni, hogy az valóban alkalmas fizikai otthon kialakítására.

A lelki otthontalanság (psychic homelessness) arra az állapotra utal, amikor az ember számára a lelki otthon valamilyen formában „lakhatatlan” vagy „nehezen lakható”. Amennyiben az otthon ideája már gyermekkorban maladaptívan alakul ki (pl. az az alaptapasztalat, hogy „az otthon az egy veszélyes hely”) vagy a késôbbiekben sérül (pl. hirtelen otthonvesztés vagy családi konfliktusok miatt), akkor többé-kevésbé lelki otthontalan emberekké válunk. Sérült gyökerû emberekké, akiknek nehézségük lesz azzal, hogy a világban, társadalomban, kapcsolataikban otthon érezzék magukat, illetve egy otthonteremtésre alkalmas fizikai helyhez olyan módon kötôdjenek, hogy az valóban alkalmas legyen fizikai otthon kialakítására (Dresser, 1985; Hoksbergen, 1999).

A jelenség megfelelố magyar elnevezését keresve választásunk azért esett az „otthontalanság” szóra, mert egyrészt a „hajléktalanság” kifejezéssel szemben tartalmazza a fizikai (lakhatás) aspektus mellett a szociális és a pszichológiai jelentéstöbbletet is (lásd lejjebb a környezetpszichológiai szemléletmód bemutatásánál). Másrészt pedig azért, mert mint ezt Bényei és munkatársai (2000) definíciós kereténél láthattuk, az „otthontalanság” a hazai szóhasználatban a hajléktalan jelenség legtágabb perspektíváját öleli fel, és mint ilyen, alkalmas egy olyan jelenség elnevezésére, amely érinti a fizikailag otthontalan emberek többségét, de egyben túl is mutat a fizikai otthontalanságon. Harmadrészt pedig emellett szólt az is, hogy a lelki otthon és a lelki hajléktalanság elnevezésére a nemzetközi irodalomban szinte kivétel nélkül a választásunknak megfelelô „home” (otthon) és „homelessness” (otthontalanság) fogalmak szerepelnek. A lelki otthon és a lelki otthontalanság konceptualizálása és operacionalizálása véleményünk szerint az ETHOS definíciós keretének fontos kiegészítése lehetne, ami a fizikai, jogi és szociális aspektus mellé integrálhatná a pszichológiai dimenziót is.

A továbbiakban a tágabb szakmai nyelvhasználatnak és a korábbi fordításoknak megfelelốen általános, köznyelvi értelemben szerepeltetjük a „hajléktalan” és a „hajléktalanság” elnevezést, míg specifikusabb elnevezéseket használunk (a cikkben szereplő definícióknak megfelelő értelemben) azokon a helyeken, ahol a hajléktalan jelenség valamely meghatározott vonatkozását szeretnénk hangsúlyozni (pl. fedél nélküliség, hajléktalanság veszélyében élôk, otthontalanok, lelki otthontalanság). 


\section{A HAJLÉKTALANSÁG PSZICHOLÓGIÁJA}

Philippot, Lecocq, Sempoux, Nachtergael és Galand (2007) a hajléktalanság pszichológiájának 1970 és 2001 közti európai irodalmát feldolgozva egyik legalapvetôbb hiányosságként azt emeli ki, hogy nincs olyan megfelelóen kidolgozott elmélet, amely a módszeres kutatáshoz alapul szolgálhatna. Amint azt korábban magunk is szóvá tettük (Kántor, 2011), az európai kutatásokból szinte teljesen hiányoznak a pszichológiai elméletek, a vizsgálatok kapcsán ritkán hivatkozott elméleti keretek többnyire a szociológiából vagy kapcsolódó tudományterületekról származnak, ami minden bizonnyal azzal magyarázható, hogy Európában a kutatások zömét e területek képviselôi végezték (Toro, 2007). A hajléktalanság kutatása a legrégebbi hagyományokkal az Egyesült Államokban rendelkezik, ugyanakkor itt is az figyelhetố meg, hogy a kutatások elméleti bázisa meglehetôsen kidolgozatlan. A hajléktalanság kutatásának egyik legjelentôsebb alakja, Toro (2007), a következô három formálódó modellt említi, melyek továbbfejlesztés esetén a jövőben segíthetik majd a hajléktalanság módszeres kutatását: az „ökológiai modell” (Toro, Trickett, Wall és Salem, 1991), a „kockázatnövelés modell” (Whitbeck és Hoyt, 1999) és a „traumamodell” (Goodman, Saxe és Harvey, 1991).

Az „ökológiai modell” (ecological model; Toro és mtsai, 1991), a közösségi pszichológia megközelítésére és Kurt Lewin (1972) korai munkásságára alapoz. A hajléktalan emberre ható teljes kontextus elemzését, a személyes, szociális, gazdasági tényezôk és a szociális ellátórendszer hatásának egyidejú figyelembevételét hangsúlyozza. A hajléktalanság okát a személyes és környezeti erôforrások hiányában látja. Ezt a modellt késôbb kiegészítették a fejlődési faktorral is, így beemelve a vizsgálat terébe például a családi kapcsolatokat is (ecological-developmental perspective; Haber és Toro, 2004).

A „kockázatnövelés modell” (risk amplification model - RAM; Whitbeck és Hoyt, 1999) a serdülôkorba, az önálló életre való felkészülés időszakába helyezi a hajléktalanná válás kapuját, és felhívja a figyelmet azokra a káros szülői és egyéb jellemzókre, melyek serdülőkorban növelik a hajléktalanná válás valószínúségét. A RAM azt hangsúlyozza, hogy a hajléktalan serdülők döntô része szétesett családi környezetból kerül ki, melyekre jellemzố az elhanyagolás, az erôszak, a konfliktusok és a szülôk szerfüggôsége. Ezek a serdülők elhagyják az otthonukat, és hasonló fiatalokkal összeállva egy olyan kapcsolati hálóba kerülnek, mely növeli annak esélyét, hogy magas kockázattal járó cselekedetek (pl. kriminális viselkedés, szerabúzus, fiatalkori prostitúció) felé sodródjanak. Így a hajléktalanság mellett az életpályát károsan befolyásoló tényezók további tömege nehezíti a hajléktalanná váló fiatalok helyzetét. A RAM modell továbbfejlesztett változata a RAAM, a „kockázatnövelés és -csökkentés modell” (risk amplification and abatement model; Milburn és mtsai, 2009), mely a hajléktalanná válás veszélyét növelô tényezôk mellett a hajléktalansággal való megküzdést segítô tényezóket is vizsgálja, illetve szemléletmódjába beépíti az ökológiai megközelítést, mely összekapcsolja a személyes és a környezeti tényezôk hatását (American Psychological Association, 2010).

Az elóbbi megközelítéssel rokon a „traumamodell” (Goodman és mtsai, 1991), mely szerint a hajléktalanná válás és a hajléktalanság traumatikus életesemények sorozatával jár együtt, növelve annak a kockázatát, hogy az érintett emberek a traumati- 
kus életesemények hatására PTSD, depresszió, szerabúzus és más negatív következmények áldozataivá váljanak. Számos tanulmány igazolta ezt a megközelítést is (American Psychological Association, 2010). Hasonló szemléletmóddal dolgozik több hazai kutató (pl. Barabásné Koller, 2006; Gyôri, 2008) is.

A Toro (2007) által kiemelt modellek mellett a hajléktalanság pszichológiai megértéséhez a következô megközelítések szintén hozzájárulnak: a hajléktalanság tanult tehetetlenség megközelítése, a szociális újraközeledési krízis hipotézis, a környezetpszichológia otthonelméletei, a posztmodern megközelítések és a kontinuum modell.

\section{A tanult tehetetlenség szerepe a hajléktalanságban}

A hajléktalanná válás egyik leggyakrabban tapasztalt velejárója a saját élet feletti kontroll elvesztésének élménye és késôbb az ebből fakadó tanult tehetetlenség kialakulása (lásd errốl Goodman és mtsai, 1991; Bandura, 1997; Molnár, 1999; Dúll, 2009).

$\mathrm{Az}$ „otthon elvesztésének folyamatában a kontroll érzésének hiánya oda vezet, hogy a hajléktalan nem tud élni a társadalom által kínált lehetôségekkel. A tanult tehetetlenség nagyon megnehezíti azoknak a közvetettebb, ideiglenes és sokkal kisebb lépéseknek (például rendszeres tisztálkodás, rendszeres munkavégzés, információszerzés vagy az önbecsülés fenntartása) a megtételét is, amely folyamat végén (elvileg) az otthon visszaszerzése áll. A tanult tehetetlenség miatt a hajléktalan [személy] nem tudja ezeket kihasználni. Mindez nagymértékú helyidentitás-vesztéssel is jár, és ezzel szoros összefüggésben természetesen nem marad érintetlen a szelfidentitás sem. Amellett, hogy a társadalom erôfeszítést tesz az otthon nélküli [személyek] anyagi támogatására, mindenképpen gyengíthetné a fenti ördögi kör hatását, ha ezek az emberek az életük fontos szféráiban valamilyen módon újra átélhetnék a kontroll érzését" (Dúll, 2009, 233-234).

\section{A szociális újraközeledési krízis hipotézis}

Saját kutatásaink (Kántor, 2005a, 2005b, 2007, 2011) szerint a felnôttkori hajléktalanság ebben az értelemben „szociális újraközeledési krízisként” is értelmezhetô. Az újraközeledés szakasza (Mahler, Pine és Bergman, 1975) az az életfázis, amikor a gyerek - optimális esetben - azt tanulja meg, hogy az anya szeretetét nem veszti el attól, hogy önálló lépésekre is vágyik. „Megtapasztalhatja azt, hogy kezdeti szárnypróbálgatási kísérletei után visszafordulva továbbra is az anya szeretete fogadja, nem pedig büntetés vagy elutasítás. Olyan életszakasz ez, melyben az érintett szenzitív minden a szimbiózisból való kiválással analóg helyzetre. Amennyiben ez a folyamat sérül, a gyermeknek egy olyan alapélménye lesz, hogy önállóvá válni veszélyes és magánnyal jár. Amennyiben önálló lépéseket tesz, számíthat a környezete szeretetmegvonására, arra, hogy soha többet nem fogják úgy elfogadni, mint önállósági törekvése elôtt. Ez az élmény elraktározódik. A fejlôdés azonban természetesen folytatódik, mígnem egy újabb, markáns veszteségélmény - általában a hajléktalanná válás közvetlen elôzményeként vagy okaként megjelenô 'elhagyási szituáció': válás, a szülôi ház elhagyása 
vagy az állami gondozás megszúnése az önálló élet kezdetén, a munkásszállás felszámolása, a börtön elhagyása a büntetés letöltése után, vagy a kórházi ellátás vége stb. - aktiválja az élményt [...] újraélesztve a szeparációs traumát” (Kántor, 2005b, 42-43). A folyamatban kialakul a hajléktalan emberekre gyakran jellemző „-talan, -telen” identitás (Kántor, 2007), ami szervesen összefügg a fentebb említett tanult tehetetlenségi állapottal is.

\section{A környezetpszichológia otthonnal kapcsolatos elméletei}

Mivel magyarul is több átfogó környezetpszichológiai írás (pl. Dúll, 1995, 1996, 2009; Sallay és Dúll, 2006; Sallay, 2008) jelent meg a témában, így csak a szorosan témánkhoz kapcsolódó gondolatok kiemelésére szorítkozunk.

Az otthon a környezetpszichológia lakókörnyezettel foglalkozó ágának központi fogalma. Az otthonnal foglalkozó környezetpszichológiai elméletek két csoportba rendezhetôk (Dúll, 1995). A moláris elmélet szerint az otthon nem egyszerúen csak földrajzi, fizikai, építészeti tér (space), hanem speciális, érzelmi, kognitív és viselkedési jelentéssel bíró hely (place) (Canter, 1977). A személy-környezet összeillés (vö. Dúll, 2009) nézete szerint pedig ,az otthon azon (nagyrészt tudatosan kialakított) környezetek egyike, ahol a személy-környezet illeszkedés leginkább megvalósulhat” (Dúll, 1995, 356).

A helyidentitás fogalma annak felismerésén alapul, hogy a helyek és azok fizikai jellemzói részt vesznek és fontos szerepet játszanak a személyiség (ki)alakulásában. A helyidentitás elmélet (Proshansky, Fabian és Kaminoff, 1983) szerint az ember szubjektív érzését, énjének kialakulását nemcsak a számára fontos személyekkel való kapcsolatai határozzák meg és fejezik ki, hanem az ôt körülvevô tárgyakhoz és helyekhez való viszonyulása is. Az énidentitás kialakulásában és folyamatos alakulásában a szignifikáns személyek mellett fontos szerepet játszanak a bennünket körülvevô tárgyak és helyek is (lásd errôl bôvebben: Dúll, 1996). A helyidentitás nem pusztán egy környezethez való tartozás érzése, hanem az én alkotórésze, egy igen összetett szelfstruktúra (Dúll, 2015a, 2015b). A legfontosabb identitásformáló referenciakörnyezet az otthon (Dúll, 1995, 2009), így a legmarkánsabb helyidentitás-vesztést az otthon szociofizikai kontextusának bármilyen formában történô teljes elvesztése okozza: „Különféle okai lehetnek az ember életmódja egészére kiható helyváltoztatásának, annak, hogy születési helyét vagy szocializációjának környezetét feladva, attól térben és kulturálisan eltávolodik, hogy azután máshol letelepedve folytassa immár idegen ként, de legalábbis idegenben az életét. A migráció és az emigráció, a kiưzetés és a peregrináció, a missziós utak és az egyetemjárások, a zarándok- és felfedezô utak, a számúzetés és a kivándorlás, a különféle pogromok, a kitelepítések, az áttelepítések vagy éppen a megélhetési nehézségek ürügyén történô áttelepülések, valamennyi exodus és szecesszió, a bevándorló, a hontalan, a disszidens vagy a menekült státusz, mind-mind egy-egy jellegzetes szociológiai alakzata azoknak az eltérô formáknak, amelyek a történelem során különbözô helyeken és idôpontokban az embert szabadon választott avagy valamilyen külsôdleges - politikai, gazdasági, vallási, természeti stb. - kényszer okán megszokott környezetének feladására késztette vagy kényszerítette” (Gábor, 2007, 73 - kiemelések 
az eredetiben). Az otthon és az otthon elvesztésének ilyen értelmezése a környezetpszichológiában nemcsak a szociológiai értelemben vett hajléktalanság értelmezésében használatos, hanem minden hosszabb-rövidebb, kisebb-nagyobb léptékú szociofizikai hely(élmény)módosulás (pl. költözés, utazás, honvágy, hely átépítése - lásd Dúll, 2009, 2015a, 2015b; Horvát, Dúll és László, 2011) alapjaiként is. A jelen tanulmányban az otthontalanságélményt a hajléktalanság összetett jelenségével az esetek döntô többségében együtt járó pszichológiai folyamatként értelmezzük. Ugyanakkor fontosnak tartjuk megjegyezni, hogy az otthonosság környezetpszichológiai fogalmának bevonása a hajléktalanság értelmezésébe valószínúleg mindkét konstruktum terminológiai finomítását és viszonyuk tisztázását kell hogy maga után vonja.

\section{Posztmodern megközelítések}

A hajléktalanság posztmodern megközelítései a merev struktúrák, rigid definíciók veszélyeire hívják fel a figyelmet, és arra, hogy a hajléktalanság hivatalosan elfogadott (pl. jogszabályokba iktatott, szociális szakma által a diskurzus alapjaként kezelt) definíciója többnyire az aktuális hatalmi struktúra érdekeit szolgálja (lásd például Watson és Austerberry, 1986; Neale, 1997). „Ahogyan a társadalom, a politika és a média foglalkozik a hajléktalansággal, nem csak a társadalmi elképzelések megtestesülése, de erôsen befolyásolja a kialakított közpolitikai válaszokat is. Vagyis a felmerülô megoldásokat elsôsorban az határozza meg, hogy kollektíven hogyan 'képzeljük el' a hajléktalanságot és annak közvetett és közvetlen okait" (Udvarhelyi, 2014, 254). Az, hogy (hajléktalan személyként, magánemberként, szakmai közösségként, kutatókként, politikusokként, társadalomként) minek tulajdonítjuk a hajléktalanságot és milyen képet konstruálunk a „hajléktalan emberről”, alapvetôen meghatározza a hajléktalanná váló emberek önértékelését, közmegítélését és a hajléktalanellátás lehetôségeit egyaránt.

A hajléktalanság ebben a megközelítésben „relatív fogalom: emberek saját nélkülözésük fokát az alapján ítélik meg, hogy mit látnak maguk körül” (Watson és Austerberry, 1989, 10). Míg egy más normákkal bíró társadalomban könnyen hajléktalannak érezheti magát az, aki vályogkunyhóban lakik, egy olyan társadalmi kontextusban, ahol a vályogkunyhó a legelterjedtebb lakhatás, a norma miatt az ott lakók nem tartanák magukat hajléktalannak. Az „otthon” nem objektív fogalom, pszichológiai értelemben nem ugyanazt jelenti mindenki számára. Mást ért alatta az, aki tömbházban nôtt fel, mint az, aki tanyáról származik. Mást jelent az otthon annak, akinek az otthona a munkahelye is (pl. mert fordítóként otthonról dolgozik), mást annak, aki „csak” aludni jár haza, mást annak, aki újszülött gyermekével minden idôt otthon tölt, mást egy gyermeknek, mást a háztartásbelinek és megint mást a viszonylag kevés idốt otthon töltô pénzkeresônek (lásd errôl például Watson és Austerberry, 1986). Az otthon élménye és az otthontalanság élménye is sokszínú. Az otthonélmény általánosnak tekinthetô módosulása/elvesztése mellett mindenki mást veszít a hajléka elvesztésével. Van, aki mindenét, a teljes életterét, míg van, aki „csak egy albérletet” vagy „alvóhelyet”, ami relatíve könnyen pótolható.

Ez a szemléletmód adja a következókben tárgyalt hajléktalanság kontinuummegközelítésének egyik legfontosabb alapját. 


\section{A hajléktalanság kontinuummegközelitése}

A hajléktalanság kontinuumalapú megközelítései arra tesznek kísérletet, hogy lágyítsanak a hajléktalanságról való gondolkodás azon túlegyszerúsítô és valóságidegen szemléletmódján, mely szerint csak „hajléktalanok” és „nem hajléktalanok” léteznek a világban, a kettô közt nincsenek átmenetek, tehát valaki vagy „hajléktalan”, vagy „nem hajléktalan”. A kontinuummegközelítés azt vallja, hogy az otthonosság, illetve hajléktalanság mértékének különbözô fokozatai egy kontinuum mentén írhatók le. Egyes modellek szerint a kontinuum mindkét végpontja a hajléktalanságon belül van (Benveniste, 1996, id. Philippot és mtsai, 2007), míg másoknál a skála a hajléktalanság és az otthonosság között feszül ki (Watson és Austerberry, 1986). A legteljesebb kontinuumok egyik végén a lakhatás teljesen kielégítő és biztonságos formái, a másik végén pedig a teljes fedélnélküliség, az utcán élés különbözó fajtái állnak (Tipple és Speak, 2005; Bényei és mtsai, 2000). A kontinuummodellek rugalmasságuk által segítik a valóságban is elmosódott határok hú leképezését, ugyanakkor kulcsfontosságú a felállított kontinuumok megfelelố szakaszolása is, hogy a probléma nagysága felbecsülhetô legyen, és lehetôvé váljon a megfelelô intervenció (Tipple és Speak, 2005). A kontinuumalapú megközelítések napjainkban meglehetôsen elterjedtek. Ide tartozó példa a FEANTSA (European Federation of National Organisations Working with the Homeless) fentebb már említett ETHOS nevú tipológiája (FEANTSA, 2005), illetve a szintén korábban már kifejtett, Bényei és munkatársai (2000) által kidolgozott hazai definíciós keret.

A bemutatott megközelítések mellett az alábbiakban egy szintén formálódó és pszichológiai szempontból nagyon ígéretes megközelítést tekintünk át, melyet a „lelki otthontalanság - lelki otthonosság kontinuum” elméletének nevezünk. A következôkben ezt az elméletet tárgyaljuk részletesebben.

\section{A LELKI OTTHONTALANSÁG ÉS A LELKI OTTHONOSSÁG}

\section{Otthonélmény: a lelki otthon}

Az, akinek van otthona, egyrészt fizikai lakóhellyel rendelkezik, másrészt pedig valami mással is, ami túlmutat az épület fizikai sajátságain, az otthonosság élményével. Annak a szükséglete, hogy valaki otthon tudja érezni magát a lakóhelyén és általában a világban, ugyanolyan elemi emberi szükséglet, mint a fizikai lakóhely szükséglete. Kennedy (2014) szerint a „pszichés otthon” egy létfontosságú lelki struktúra, mely több különbözố humán funkciót sûrít magába. A lelki otthon bizonyos szempontból az otthon ideája, az identitásunk alapja, annak a lenyomata, hogy honnan származunk és kik is vagyunk valójában. Eredeti otthonunk nem pusztán téglákból és egyéb építôanyagokból állt, nem is csak a fizikai környezetból és a belsố terekból, hanem érzelmi légkörből és kapcsolati élményekből is.

Az, hogy mit jelent számunkra az „otthon”, milyen a mi otthonunk és milyen tudatos, illetve testi/zsigeri élményt hordunk magunkban arról, hogy milyen érzés otthon lenni, alapvetốen meghatározza az identitásunkat és azt, hogy hogyan érez- 
zük magunkat a világban. Kennedy (2014) szerint a pszichés otthon, az otthonosság belsố élménye azt jelenti, hogy életünknek van bázisa, rendelkezünk a biztonságos otthon hátterével, van egy hely, ahova alanyi jogon és megkérdójelezhetetlenül tartozunk. A pszichés otthon a fejlôdô identitás számára szervezô pszichés struktúraként szolgál.

\section{Nem mindenkinek ugyanolyan a lelki otthona}

A lelki otthon sokféle lehet. Például feltehetôen más egy anyagi bôségben felnôtt ember otthonideája, mint egy mélyszegénységben élőé, vagy más körülmények közt érezheti otthon magát az, aki egy tanyán nôtt fel két szülōvel és három testvérrel, és máshol az, aki egy nagyvárosi tömbházban egykeként. Az otthonossági érzés, a lelki otthon milyensége összetett ember-környezet illeszkedés eredménye (környezet alatt itt a környezetpszichológia által hangsúlyozott sokrétû szociofizikai környezetet értve, lásd pl. Dúll, 2009). Az ember legtöbbször ott van otthon, ahol felnevelkedett és szocializálódott. Abban a közegben, amelyben megtanult boldogulni, ahol „otthonosan”, rutinosan mozog (Dúll, 2012a). Ez az otthonosság nem feltétlenül jelenti azt, hogy az adott közeg pozitív, az egyén fejlődését segítô, pusztán azt, hogy ismerôs, és az illetô múködésmódja, személyisége, viselkedése ehhez alkalmazkodott, és megtanulta, hogy az adott környezetben hogyan tud életben maradni. Fenomenológiai értelemben az otthonlét élményérôl beszélünk (at-homeness, Seamon, 2000). Az otthonlét élményének kialakítási formája ugyanakkor nagyon speciális is lehet. Nagyon eltérô szociofizikai környezetekben az adaptív viselkedés, a megküzdés olyannyira eltérô, hogy ami az egyik helyzetben patológiás életvitelnek számít, a másikban teljesen normális. Az egyik ember otthona, lehet, hogy mások számára veszélyes. Például az ôserdôben élô ember otthona a jóléti társadalmak nagyvárosaiban élôk számára életveszélyes lehet, ugyanakkor annak, aki az ôserdôben nôtt fel, lehet, hogy ez a világ legbiztonságosabb helye és a „civilizált” nagyvárosba kerülve érezné magát kiszolgáltatottnak és teljesen gyökértelennek. De nem is kell ilyen messzire mennünk. Gondoljunk egy olyan emberre, aki mélyszegénységben nôtt fel és 30 éve hajléktalanul él Budapesten, megszokta az utcai életet és az évek során, minden bizonnyal számtalan szörnyú traumát átélve, de megtanult az utcán élni. Ide köti az évtizedek óta megszokott életvitele és itt ápolja a számára fontos kapcsolatokat. Bár - az átlagember gondolkodásával - nehéz elképzelni ennél mostohább helyzetet, mégis elképzelhetô, hogy számára, jelen élethelyzetében a világ legotthonosabb helye az a tér és néhány utca, ahol „lakik”. Otthonát nem határolják falak, sokkal inkább a hely ismerete és annak tudása, hogy az itt jelentkezó nehézségekkel hogyan lehet megküzdeni, ezek között a körülmények között hogyan lehet életben maradni.

Még egyszer hangsúlyozzuk, hogy az ember számára aktuálisan legotthonosabb hely nem feltétlenül az, ahol számára a legjobbak a fejlôdés és a továbbfejlôdés feltételei. Viszont ez az a hely, ahol önként vagy kisebb-nagyobb kényszer hatására sok idôt töltött és így „belakta” azt. Az a hely, ahol a világ minden helye közül a legnagyobb biztonsággal mozog, mert ismeri az adott közeg játékszabályait. Elég talán, ha az otthonról elköltözô fiatal felnôtt példáját vesszük, aki „útra kel”, vállalja az ezzel járó krí- 
zist annak reményében, hogy a jelenlegi megszokott, belakott, ismert környezeténél „jobbat” találjon, jó esetben bízva abban, hogy a belsố igényeihez jobban illeszkedô, a fejlôdési irányának teret adó szociofizikai környezetet tud majd valahol találni vagy kialakítani.

Tudjuk, hogy az ismerôs, számunkra otthonossá vált szociofizikai környezet markáns megváltozása krízisállapothoz vezet (pl. Horvát, Dúll és László, 2006), függetlenül attól, hogy jobb vagy rosszabb körülmények közé kerülünk. A környezet, amelyben élünk, ahol lakunk, ahova napi rutinunk (vö. Dúll, 2012a) beágyazódik, amely kapcsolataink számára teret ad, identitásunk fontos építôköve. A szociofizikai környezet jelentôs megváltozása identitáskrízist provokál, megkérdőjelezve azt, akik vagyunk (vö. Dúll, 2015a). Az otthonos környezet elvesztésének egyik legkirívóbb példája a hajléktalanná válás, ami szintén nem pusztán a lakás elvesztését jelenti, hanem az érintett életét minden szinten átstrukturáló életeseményt. Hasonló krízis állhat elô akkor is, ha a megszokott környezet meglehetôsen káros, így például, ha egy az utcai élethez szokott hajléktalan élethelyzetben éló ember a rehabilitáció folyamatában elveszti a megszokott utcai környezetét és egy olyan közegbe kerül, amely - bár a közmegítélés szerint lakhatásra sokkal alkalmasabb - számára már nagyon idegen. Ez külön kihívást jelent krónikusan hajléktalanságban élô emberek rehabilitálása során.

\section{A lelki otthontalanság}

A „lelki otthon” fontosságát többen a hiány oldaláról, a „lelki otthontalanság” leírásával hangsúlyozzák. A kifejezésnek több szinonimája létezik, melyek közül a mentális otthontalanság (Melamed, Shalit-Kenig, Gelkopf, Lerner és Kodesh, 2005), a családi tûzhely nélküliség (Moore, Canter, Stockley és Drake, 1995), az érzelmi otthontalanság (Bernstein és Foster, 2008) és a pszichés otthontalanság (Dresser, 1985; Hoksbergen, 1999) a legelterjedtebbek.

\section{Gyermekek és fiatal felnôttek lelki otthontalansága}

A jelenség elsô leírását Iain Dressernél (1985) találtuk, aki angliai és walesi állami gondozott gyermekek pszichológiai otthontalanságáról számolt be. Véleménye szerint ezek a gyermekek, bár fizikailag nem otthontalanok, lélektani értelemben annak tekinthetôk. Dresser szerint a jelenség az állami gondozott gyermek sok sebból vérzô neveltetésének köszönhetô. Hangsúlyozta, hogy amennyiben a pszichológiai otthontalanságukat nem tudatosítjuk és megfelelố pszichoterápiás ellátással nem kezeljük, ezeknek a gyerekeknek a pszichológiai otthontalansága nem fog oldódni. Ez oda vezethet, hogy sérült felnôttekké fognak válni, akik továbbadják az általuk megélt hiányokat a következó generációnak. Esetelemzésekkel példázza, hogy az általa kezelt állami gondozott gyermekek döntố többségénél a sérülés forrása a szülők személyisége, akik képtelenek voltak biztonságos és szeretô otthont biztosítani a gyermek számára, és akik a gyereket elhanyagolásnak, valamint sok esetben fizikai és szexuális erôszaknak tették ki. 
A jelenség egyik legalaposabb vizsgálata Hoksbergen (1999) szociálpszichológus nevéhez kötốdik, aki kutatócsoportjával az Utrechti Egyetemen több mint 10 éven keresztül vizsgált nyolcvan örökbe fogadott gyermeket. Vizsgálatuk központi koncepciója a „pszichés otthontalanság” (psychic homelessness) volt. Azt találták, hogy pszichés otthontalanságuk miatt az örökbe fogadott gyermekek speciális ellátásra és figyelemre szorulnak azt követôen is, hogy kedvezô és biztonságos otthont adó családba kerültek. A „van otthonom” kifejezés azt az érzést takarja, amikor valaki azt éli meg, hogy „biztonságban van egy adott fedél alatt, és nyilvánvaló érzelmi kötôdése van az otthonához és az emberekhez, akik ott élnek” (Hoksbergen, 1999, 105). „Amit itt hangsúlyozok, a pszichológiai értelmú otthontalanság, pszichés otthontalanság. Ez alatt emberek azon élményét értem, hogy nem teljesen tartoznak abba a családba, amelyben felnôttek, amelyben a gyermekkoruk nagy részét töltötték. Ez elégtelen kötôdést okoz és gyökértelenségérzést" (Hoksbergen, 1999, 106). Örökbefogadott emberek élménybeszámolókban (Verrier, 1993, id. Hoksbergen, 1999) azt fogalmazzák meg, hogy „úgy érzik, mintha egy részük hiányozna” vagy „egy nagy üres lyukat élnek meg magukban”. Nagyon sok örökbe fogadott személy arról számolt be, hogy ô mint gyermek, az ôt világra hozó anya számára helyet ôriz magában, függetlenül attól, hogy az örökbe fogadó szüleivel mennyire közel állnak egymáshoz. A jelenség magyarázatát Hoksbergen a szociálpszichológia referenciacsoport fogalmára építi, mely azt a csoportot jelenti, mellyel a személy azonosul, mellyel kielégítő kapcsolata van, és melynek normái és értékei bizonyos mértékben a személy sajátjaivá váltak és az önértékelésének alapját képezik (Rabbi, 1992, id. Hoksbergen, 1999). Ebben az esetben az örökbe fogadott gyermek, az ô vér szerinti családja és az örökbefogadó család közötti viszonyról beszélünk. Mindkettô mikroreferencia-csoportnak tekinthetô az örökbe fogadott gyerek szempontjából. Az örökbe fogadó család számít az örökbefogadott legfontosabb mikroreferencia-csoportjának, ugyanakkor, ahogy a gyermek felnô, kiderül, hogy a vér szerinti család is fontos referencia. Az örökbefogadottak többségénél legalább idôlegesen megjelenik a „kettő között” érzése. Fantázia szintjén vagy valós keresésben megnyilvánulva a legtöbb örökbe fogadott embert foglalkoztatja a kérdés, hogy honnan származik.

Hoksbergen szerint fontos számításba vennünk, hogy az otthontalanság vagy annak érzése, hogy „a gyökereink ki lettek tépve”, előfordulhat számos különbözô helyzetben és csoportban. A lelki otthontalanság sokakat érint, és nagyon komoly következményei lehetnek. Az érintettek egy csoportja, a fentebb említett nevelôotthonban felnôtt gyermekek, akik többségének fogalma sincs róla, hogy kik a vér szerinti szüleik. Egy másik csoport, azok, akik az anyjuk mellett nôttek fel, de nem ismerik az apjuk kilétét (az anya sem tudja, vagy mesterséges megtermékenyítéssel fogantak stb.). Ennek speciális alcsoportja az elvált szülő́k gyermeke, akinek a nevelôszülôje teljesen megszakítja a kapcsolatot a korábbi társával. Egy harmadik csoport az (adott országból származó vagy külföldrôl) örökbe fogadott gyermekek.

A jelenség kezelésével kapcsolatban Hoksbergen kiemeli, hogy tapasztalata és kutatási eredményei szerint az életben való hazatalálás egyik fontos feltétele, hogy az érintett saját pszichés hajléktalanságát át tudja élni és meg tudjon vele barátkozni.

A Dresser és Hoksbergen által képviselt nézeteket támogatják Bernstein és Foster (2008) eredményei is, akik 208 korábban megélt vagy jelenleg is hajléktalan 13 és 25 
év közötti fiatallal készítettek interjút 23 kaliforniai városban, annak érdekében, hogy megismerjék élményeiket, szükségleteiket és nézeteiket. Azt találták, hogy azok a fiatalok, akiknél állami gondozás elôzte meg a hajléktalanná válást, arról számoltak be, hogy egyfajta „érzelmi otthontalanságot” (emotional homelessness) éltek át már jóval a fizikai hajléktalanná válásuk elốtt. Otthontalanságukat jóval korábbra datálták annál, hogy valójában fizikailag otthontalanná váltak volna.

Moore és munkatársai (1995) arra a kérdésre keresték a választ, hogy miért van az, hogy az átmeneti vagy instabil lakhatással rendelkező fiatalok egy része magát otthontalannak éli meg. A probléma megnevezésére kidolgozták a „családi túzhely nélküliség” (hearthlessness) koncepcióját, azon lakhelyek esetére, melyek lakóiknak nem jelentenek valódi otthont.

Hasonló eredményre vezettek Riggs és Coyle (2002) kutatásai is, akik 16 és 25 éves koruk között hajléktalanságot átélt angol fiatalokkal készítettek mélyinterjúkat, és az otthontalanság fizikai és pszichológiai komponenseit vizsgálták. Azt találták, hogy a saját család általi elutasítottság élménye sok esetben „pszichológiai otthontalanság” érzéséhez vezet. A fizikai és a pszichológiai otthon elkülönülését jól szemlélteti a következô, általuk idézett interjúrészlet: „Lehet egy házad - ... lehet egy bázisod vagy bármid, de elôfordulhat, hogy nem fogod otthonnak érezni... Mindenki ismeri a hajléktalanság mítoszát - az utcán vagy mit tudom én -, de a helyzet egyáltalán nem ez... Úgy gondolom (otthontalannak lenni) inkább olyan, mint nem tartozni sehova, nem érezni azt, hogy tartozol egy bizonyos helyhez" (Riggs és Coyle, 2002, 13).

\section{A pszichiátriai betegek lelki otthontalansága}

Melamed és munkatársai (2005) klinikai tapasztalataikra alapozva azt feltételezik, hogy a fizikai otthontalanság mögött sok esetben egy sajátos elmeállapot létezik. Betegeik egy részénél azt vették észre, hogy határozottan a hajléktalanná válás felé tendálnak. Feltételezték, hogy ez egy belsố struktúra meggyengülésére vagy szétesésére utalhat, ahhoz az állapothoz vezetve, amit „mentális otthontalanságnak” neveztek el. Ebből a megközelítésbôl az, hogy a betegek a konkrét hajléktalanságot „választják”, vezetô tünetnek tekinthetô. A háttérben traumatikus gyermekkori élményeket feltételeznek, melyek következtében az egyén szélsôségesen ragaszkodik ahhoz a beállítódáshoz, hogy: „Nincs szükségem segítségre, minden szükségletemet képes vagyok kielégíteni.” Az egyén egy képzeletbeli tökéletes világhoz ragaszkodik, amelyben nincs helye semmilyen fájdalomnak vagy hiánynak. Ezzel egy idóben azonban a hajléktalanság maximális függôséget és hiányállapotot hordoz, amelynek drámája a létért való küzdelemre tevôdik át, így egyszerre elfedve és felfedve az eredendô sebzettséget.

Bizonyos szempontból azt mondhatjuk, hogy a lelki betegségeink a „belsố otthonunkban” fejlôdnek ki. Ezzel az otthon funkcióira (védelem, megtartás, tükrözés stb.) utalunk, amelyek anyai tárgykapcsolati funkciók (Kohut, 1986, id. Melamed és mtsai, 2005). Amikor sérül a kapcsolat a számunkra fontos szelftárgyakkal, akkor sérül az otthon funkció - az anyai környezet -, és ezen keresztül a független szelf kifejlódésének potenciálja is. Ogden (1986) szerint abban a folyamatban, amit Winnicott az egyedüllét képességének kifejlôdésérôl leírt, nem az anya mint tárgy válik belsôvé, hanem az anya 
mint környezet. Gale és munkatársai (2008) szerint az osztályos pszichiátriai ellátásban részesülô pszichotikus betegek bizonyos szempontból „kilakoltatottak”, meg vannak fosztva a számukra otthonos közegüktôl, s így pszichés hajléktalanságot élnek át. „Lenni” mindig helyhez kötött: lenni valahol. Mindig a fizikai környezetünkkel együtt és azzal összefüggésben létezünk. Gale (2000) azt vallja, hogy a skizofrének mindig „ki vannak mozdulva a helyükrôl”, lelki otthontalanságot élnek át függetlenül attól, hogy fizikailag hol vannak. Gale szerint a megfelelő terápiás lakhatást biztosító rezsimek hatékonysága is azzal magyarázható, hogy segíti az érintetteket abban, hogy visszaszerezzék annak az érzését, hogy helyet foglalnak, hogy a külvilágban laknak. Mindez mélyen összecseng a környezetpszichológiából ismert, fentebb már idézett helyidentitás-elmélettel (Proshansky és mtsai, 1983; lásd errôl bốvebben: Dúll, 1996, 2015a, 2015b).

A pszichiátriai beteg hajléktalan emberek ellátása mindig sajátos problémát jelentett az ellátó intézmények számára. Ugyanakkor a belsô mentális otthontalanság kérdése korábban még nem volt vizsgálat tárgya. Az ellátórendszer általában a hajléktalan emberek konkrét mindennapi problémáira összpontosított. A mentális otthontalanság egy paradigmatikus leíró modell lehet, mely megváltoztathatja a terápiás megközelítést. Abba az irányba hathat, hogy rehabilitáció során terápiás erôfeszítést tegyünk a mentális otthon kifejlesztésére és/vagy megerôsítésére azon klienseknél, akik belsô otthona hiányzik vagy nem képes a szerepét betölteni. Az otthon vagy az otthontalanság - mint metafora - érthetố a kliensek számára. Az otthon metaforája jó (és többnyire biztonságos) alapot - átmeneti teret - adhat egy párbeszéd számára az otthonról mint helyrôl, de az otthonról úgy is beszélhetünk, hogy az ént értjük az otthon metaforája alatt (vö. Peled és Schwartz, 1999).

Melamed és munkatársai (2005) a mentális otthontalanság koncepcióját további vizsgálatra érdemes munkahipotézisnek szánják, mely inspiráló lehet a pszichiátria és más területek (pl. a szociológia, szociális munka, pszichológia) számára egyaránt. A terápiás munkában a mentális otthontalanság koncepcióját hasznos eszköznek találták, amely segít a kliens élettörténetének és életérzésének megértésében. Ez az eszköz hasznosnak bizonyult az effektív hajléktalan klienseknél és azoknál a klienseknél is, akik nem voltak érintettek fizikai hajléktalanságban.

\section{Helyveszteség esetén átélt lelki otthontalanság}

Fentebb említettük, hogy a lelki otthontalanság, a helyveszteség élménye a lakóhely-változtatást megélookre is érvényes kategóriának tûnik (Dúll, 2009, 2015a, 2015b). A lakóhely-változtatás során a személy vagy csoport gyászt és identitáskrízist él át. A lakóhely-változtatás legtöbbször különbözô szintű és számú veszteségélményt (pl. közösség, kapcsolatok, lakóhely, munkahely elvesztése) és identitásváltozást von maga után. A korábbi lakóhely elvesztése miatti gyásszal és az új közeghez való alkalmazkodás krízisével való megküzdés jóval nehezebb és elhúzódóbb azoknál, akik országhatárt lépnek át a költözés során, mint azoknál, akik határon belül költöznek egy másik helyre (Horvát és mtsai, 2006).

Carole Boyce-Davies (1994) érzékletes leírását és elemzését adja az otthonukat vesztett, gyökértelenné vált elvándorlók fizikai és lelki otthontalanságának. A migráció 
honvágyat (vö. Horvát és mtsai, 2011), otthontalanságélményt szül, és elindít egy folyamatot, mely során az „otthon” fontossága érezhetôvé válik. Az otthonukból elûzött vagy kényszerúen elvándorolt emberek élményeinek tanulmányozása láthatóvá teszi, hogy fizikai és lelki otthontalanság egyaránt létezik. A migráció és a kiûzetés (számúzetés) az emberiség egyik legfontosabb alapélménye. Az áttelepülés és a gyökértelenség az „Új Világ” élményének implicit része. Minden áttelepülés az identitás definiálását és újradefiniálását teszi szükségessé.

A külföldi örökbefogadott gyermekeknél, akiket idôsebb korukban fogadtak örökbe, sokszor reaktív kötôdési zavart (RAD) diagnosztizáltak és késôbb, felnôtt korban pszichés otthontalanság érzése volt megfigyelhetô náluk (Hoksbergen és Laak, 2000).

\section{Lelkileg otthontalanná válás családon belüli erôszak miatt}

„Azokat az embereket nevezzük 'otthon-otthontalanoknak' (Homeless-at-Home), akik magukat otthontalanokként definiálják annak ellenére, hogy (a hajléktalanság hivatalos definíciója alapján) adekvát lakhatással rendelkeznek. Fizikai vagy szexuális abúzus gyakran vezet ahhoz az érzéshez, hogy 'otthon-otthontalanok' vagyunk" (Wardhaugh, 2012, 163).

Az otthontalanságnak ez a láthatatlan formája, mely többnyire nôket és gyermekeket sújt, felhívja a figyelmet arra, hogy az, ami külsô szemmel és jogi, igazgatási vagy szociológiai definíció szerint otthon, az lélektani értelemben nem feltétlenül az. Sokszor előfordul ugyanis, hogy az „otthon” nem képes betölteni védelmezó, biztonságot adó szerepét, hanem veszélyesebb hellyé válik, mint a külvilág. Az otthontalanná válók között jelentôs azok száma, akik erôszak elool menekülnek a hajléktalanságba, ami ebben az esetben egyrészt fizikai deprivációt és identitásvesztést jelenthet, másrészt emellett viszont kiszabadulást is az otthoni terror alól (Wardhaugh, 2012). A terület kutatóinak többsége az otthonról elmenekült és hajléktalan nôk esetén 40 és $50 \%$ közé becsülik az erôszak áldozatainak arányát (Wardhaugh, 2012). Annak valószínúsége pedig, hogy valaki szexuális vagy egyéb fizikai erôszak áldozatává válik, minden hajléktalanul eltöltött évvel nô, a férfiak és a nôk esetén egyaránt. Az pedig, hogy ez az erôszak sokszor nyilvános helyen történik, a jelenségre nem reagáló „közönség” elôtt, ördögi körként csak tovább súlyosbítja az áldozat bizalomvesztését és sebzettségét.

\section{A fizikailag hajléktalan ember lelki otthontalansága}

Véleményünk szerint a fizikai hajléktalan emberek esetén mindig számolni kell a lelki otthontalanság jelenlétével, ugyanis esetükben szinte kivétel nélkül az élettörténet része az otthon sérthetetlenségébe és biztonságába vetett bizalom elvesztése (pl. a Hoksbergen által leírt korai sérülések következtében, amikor „a biztonságos otthon” élménye ki sem alakulhatott) vagy legalábbis a bizalom sérülése (hiszen mindannyian elvesztették otthonukat). 
Toye (2008) „érzelmi otthontalannak” nevezi a hajléktalan emberek populációjának azon tagjait, akik olyan fokú bizalomvesztést éltek meg, hogy nem képesek felismerni és használni a helyzetük jobbítására rendelkezésre álló segítséget. Véleménye szerint ezeknél az embereknél az otthonosság alapjai sérültek, és az érzelmi szinten bekövetkezett otthontalanná válás tekinthetô fizikai hajléktalanságuk valódi gyökerének. Kiemeli, hogy annak, hogy képesek legyünk egy adott új közegben hazatalálni, illetve otthonunkat újraalkotni, nagy valószínúséggel feltétele az, hogy legyen elôzetes élményünk arról, hogy milyen otthon lenni valahol.

Bényei és munkatársai (2000) fizikai értelemben hajléktalanná váló embereknél figyelték meg, hogy a különbözó élethelyzetek változása során az érintettek maguk is „szubjektív változó formában élik meg helyzetük mibenlétét, s ennek függvényében identifikálják magukat hajléktalanoknak egy-egy stáció esetén: akkor, amikor fedél nélkül maradnak, vagy már akkor, amikor éppen elvesztették stabil lakhatásukat, illetve akkor, amikor nem találják helyüket zsúfolt és lakhatatlan 'lakásukban'” (Bényei és mtsai, 2000, 68).

A lelki otthontalanság és a fizikai hajléktalanság kapcsolatát Hoksbergen (1999) abban látja, hogy a hajléktalan emberek döntô többsége gyermekkorban súlyos fizikai és lelki elhanyagolást élt át, szüleik elutasították óket az elsô éveikben. Hollandiában a hajléktalan emberek $70 \%$-ánál találták azt, hogy töltött idôt gyermekotthonban (Magyarországon a hajléktalan emberek között a korábban állami gondozásban levôk aránya jóval alacsonyabbnak tûnik, lásd pl. Gyôri, 2008). A biológiai szüleik mellett sérült az alapvető biztonságérzésük. Ezeknek a gyermekeknek alapjaiban károsodott az identitásérzése, valamint a bizalma önmagukban és másokban. Többségük késôbb gyakran szociális zavarokkal és kötődési nehézségekkel küzd, hajlamosak lehetnek például szociális izolációra, deviáns viselkedésre és fokozott törekvés jellemezheti óket arra, hogy - akár kritikátlanul - mások kedvében járjanak.

\section{A hajléktalanság veszélyében élók lelki otthontalansága}

A hajléktalansággal foglalkozó szakirodalomban gyakran emlegetett csoport a „hajléktalanság veszélyében élók”, akik az „effektív hajléktalan” populáció fő utánpótlását jelentik. Ide társadalmunk azon csoportjai tartoznak, melyek tagjai a hajléktalanná válás közvetlen veszélyében élnek, és esetükben sokszor elég még egy csepp a pohárba ahhoz, hogy kikerüljenek az utcára (Gyôri, 1990). Ide tartoznak a súlyos szegénységben élôk, az alkohol- és drogabúzussal küzdôk, a pszichiátriai betegek, a súlyos egészségügyi problémákkal, testi betegségekkel küzdôk, az állami gondozásban nevelkedôk, a börtönben levôk, illetve a büntetett elóéletúek és a hospitalizáció (vagy az institucionalizáció más formáinak) áldozatai (American Psychological Association, 2010). Fontos észrevennünk, hogy mindegyik olyan csoport, melynél megfigyelték a lelki otthontalanságot, vagy a fizikailag hajléktalan emberek populációjából származik, vagy a hajléktalanság veszélyében éloonek minôsül.

Azt, hogy a hajléktalanság veszélyében élôk közül ki válik hajléktalanná és ki nem, minden bizonnyal személyes és strukturális tényezók komplex összjátéka határozza 
meg. Valószínúsíthetô, hogy a lelki otthontalanság érzése az egyik fizikai hajléktalanság irányába ható személyes tényezô. Ebben az esetben pedig a hajléktalanság veszélyében élốk populációjának hajléktalanságra fokozottan veszélyeztetett alcsoportja azoké, akik lelkileg már otthontalanok.

\section{Hétköznapi fizikai és lelki otthontalan állapotaink}

P. L. Berger és munkatársai (1974) az otthontalanná válást a modernizáció melléktermékének tekinti. Véleményük szerint az otthon metafizikai elvesztésének élménye kortünetnek tekinthetô. Niit (1993, id. Dúll, 1996) is a megszokott kereteken (hajléktalan emberek, illetve hajléktalanság veszélyében élôk körén) kívül helyezi az otthontalanság élményét, amikor a „mentális otthontalanság” élményét írja le a lakótelepi magas házak lakóinál, akiknek lakása mind az identitás kialakításában, mind annak kommunikálásában diszfunkcionális. Véleménye szerint ebból fakadóan családok sokaságának fizikai értelemben van ugyan otthona, de tökéletes pszichológiai értelemben nincs.

A teljesen átlagos élethelyzetnek tekinthetô költözéssel kapcsolatban már az 1930-as évek végén kimutattak pszichológiai nehézségeket (vö. Dúll, 2012b). Taylor (1938 idézi Halpern, 1995) például leírta az ún. külvárosi neurózis jelenségét. A külvárosi neurózis az új lakónegyedekbe költözött lakók - elsôsorban a nôk - esetében volt kimutatható. Az elköltözöttek élményeiból kiderült, hogy például a környék ismeretlensége, a munkahely távolságának növekedése, a családi kapcsolatok lazulása, az egyéb szociális kapcsolatrendszerek nehéz fenntarthatósága és az általános izoláció élménye állt a jelenség hátterében. Toyle (2008) szintén kiterjeszti a lelki otthontalanság élményét, amikor kiemeli, hogy költözések alkalmával mindannyian keresztülhaladunk olyan idôszakokon, amikor nem érezzük otthon magunkat, és többnyire megéljük, hogy hosszabb-rövidebb idôre van szükségünk ahhoz, hogy megszokjuk új környezetünket. Ezekben az idôszakokban többé-kevésbé belekóstolunk a lelkileg otthontalanság élményébe.

Az otthonosság élménye legalább olyan fontos az ember számára, mint az, hogy fedél legyen a feje fölött. A pszichés otthon az emberi élet és az identitás alapja, egy szervezô lelki struktúra, mely központi szereppel bír a személyes identitás megfogalmazásában (Kennedy, 2014).

\section{A LELKI OTTHONTALANSÁG - LELKI OTTHONOSSÁG KONTINUUM ELMÉLET FÖ TÉTELEI}

A fentiek nyomán saját vizsgálataink (Kántor, 2005b; Kántor és Dúll, 2013; Kántor, Brózik és Dúll, 2018) számára a következô tesztelésre érdemes elméleti keretet alakítottuk ki:

1. Mindenki számára létezik lelki otthon (Kennedy, 2014), az a létfontosságú pszichés struktúra, mely alapvetôen meghatározza azt, hogy hogyan érzi magát, hogyan él a világban és milyen érzelmei, attitúdjei stb. vannak az ôt körülvevô szúkebb és tágabb 
szociofizikai környezettel kapcsolatban. Ez a struktúra, a bennünk élô otthon ideája, mely magába sûríti annak belsố élményét, hogy milyen az életünk bázisa. Arról szól, hogy az átélt tapasztalatok eredményeként hova tartozónak éljük meg magunkat? Milyen „otthon” hátterével rendelkezünk? Volt-e, illetve épen megmaradt-e bennünk egy olyan hely, ahova alanyi jogon és megkérdôjelezhetetlenül tartozunk? A lelkileg otthonos ember egészséges "gyökerekkel” rendelkezik, aminek köszönhetôen képes otthon érezni magát a világban, társadalomban, kapcsolataiban, illetve egy otthonteremtésre alkalmas fizikai helyhez olyan módon képes kötődni, hogy az valóban alkalmas fizikai otthon kialakítására.

2. A lelki otthon kialakulása a saját szociofizikai otthonnal kapcsolatos kora gyermekkori tapasztalatokhoz köthetô, ahhoz, hogy olyan otthont adó családban nevelkedett-e fel az ember, amely védelmezte, megtartotta, tükrözte stb. ót és így forrása lehetett a védettséget, tartalmazást, tükrözést, belsố biztonságot stb. adó intrapszichés struktúrának (Melamed és mtsai, 2005). Amennyiben a lelki otthon, a bennünk élô otthon ideája már gyermekkorunkban maladaptívan alakul ki (pl. azt tanuljuk meg, hogy „az otthon egy veszélyes hely”) vagy a késôbbiekben sérül, akkor többé-kevésbé lelki otthontalan emberekké válunk. Sérült gyökerú emberekké, akiknek nehézségük lesz azzal, hogy a világban, társadalomban, kapcsolataikban otthon érezzék magukat, illetve egy otthonteremtésre alkalmas fizikai helyhez olyan módon kötôdjenek, hogy az valóban alkalmas legyen fizikai otthon kialakítására (Dresser, 1985; Hoksbergen, 1999). A pszichológiai, mentális, lelki, illetve az érzelmi otthontalanság, valamint a családi tûzhely nélküliség egyazon jelenség különbözô szintû és intenzitású változatainak tekinthetô. A jelenség együttes megragadására a lelki otthontalanság kifejezés használatát javasoljuk.

3. Nem minden fizikailag otthontalan ember lelkileg otthontalan, és nem minden lelkileg otthontalan ember válik fizikailag is otthontalanná. A lelki otthonosság nem feltétlenül mozog együtt azzal, hogy valaki jogi, közigazgatási szempontból milyen fizikai lakhatással rendelkezik. A fizikai otthontalanság és az otthontalanság élménye két olyan dimenziót alkot, melyek bár gyakran együtt járnak, nem mindig járnak együtt. A lelki otthonosság élménye egy intrapszichés jellemző, melynek kapcsolata közvetlenebb az egyén otthonossággal kapcsolatos korábbi tapasztalataival, mintsem a lakó- vagy tartózkodási helye jelen paramétereivel, bár az ember-környezet tranzakció (Altman és Rogoff, 1987 - lásd Dúll, 2009) jegyében az utóbbiaktól sem független.

4. A teljes otthontalanság és a teljes otthonosság egy kontinuum két végpontjának tekinthetô, melyek közt számtalan köztes, átmeneti állapot helyezkedik el (pl. Watson és Austerberry, 1986). Ez a tétel fizikai és lelki szinten egyaránt érvényes. Ugyanakkor a kontinuum mentén számolhatunk és fontos is számolnunk diszkrét kategóriákkal, melyek segítségével megragadható és kezelhetô, hogy a hajléktalanság bizonyos fokán álló emberek igazgatási, jogi, ellátási stb. szempontból milyen csoportba tartoznak és ehhez mérten például milyen ellátásra szorulnak.

5. Akárcsak a fizikai otthontalanságnál (lásd Arce és Vergare, 1984; Komáromi, 1994), a lelki otthontalanság esetén is fontos különbséget tennünk aközt, hogy valaki (a) krónikus, (b) szituatív vagy (c) epizodikus otthontalan. A lelki otthontalanság szintjén a fenti három aspektus megfelelője: (a) „lelki otthontalan személyiségrôl”, azoknál, akik esetén döntôen a korai élmények hatására a lelki otthontalansággal ál- 
landó személyiség szintú alapállapotként kell számolnunk; (b) aktuális életesemény (pl. költözés, válás), szituatív krízis által kiváltott „lelki otthontalan állapotról”; és (c) olyan emberekrôl, akiknél „visszajáró” lelkület a lelki otthontalanság, lelkiállapotukra az jellemzô, hogy rendszeresen az otthonosság és otthontalanság élménye között ingáznak, életük lelki otthontalan epizódokkal tarkított. Ebben a megközelítésben valaki a lelkivilága különbözó szintjein egyszerre lehet lelkileg otthonos és lelki otthontalan, például akkor, ha a személyisége szintjén a „lelki otthona” ép, de az aktuális élethelyzetében épp lelki otthontalanságot él át.

A lelki otthontalanság - lelki otthonosság elméletét további vizsgálatra érdemes koncepciónak tekintjük, mely segíthet a hajléktalanság pszichológiájának megértésében és átfogó megragadásában, és a terület nyitva maradt terminológiai, elméleti, módszertani és gyakorlati kérdéseinek megválaszolásában.

\section{ÖSSZEGZÉS}

Az elmúlt, a hajléktalanellátás alapjait lefektetô korszakban Magyarországon a szakma elsôsorban a hajléktalanságot kiváltó-fenntartó strukturális, társadalmi okokra, folyamatokra összpontosított, és közben háttérbe szorultak az egyéni életpályákat befolyásoló finomabb meghatározó tényezôk, melyek megragadása és kezelése a hajléktalanellátást sokkal hatékonyabbá tehetné (Bényei és mtsai, 2000). Annak ellenére, hogy a hajléktalansággal foglalkozó szakma elméleti konszenzusa vallja a személyes tényezők fontosságát, a hajléktalanság intrapszichés vonatkozásainak kutatása meglehetôsen elhanyagolt. Cikkünkkel erre a hiányra kívántunk reagálni. Ismertettük az otthontalan emberek élményvilágát megragadó „lelki otthon” és „lelki otthontalanság” irodalmát. Reményeink szerint a lelki otthontalanság koncepciója és a bemutatott lelki otthontalanság - lelki otthonosság kontinuum elmélet kutatási és prevenciós szinten egyaránt kiegészítôje lehet a már létezô, az otthontalanságot elsôsorban fizikai és szociális szinten megragadó modelleknek (Bényei és mtsai, 2000; FEANTSA, 2005; Busch-Geertsema és mtsai, 2010).

Megközelítésünkben a hajléktalanság komplex problémaként értelmezendô, melynek kezelése interdiszciplináris megközelítést igényel. Az otthontalan embereknek az effektív hajléktalanság veszélyéból való tartós kivezetéséhez meggyôzôdésünk szerint a lakhatás rendezésére és a „lelki otthon” helyreállítására egyaránt szükség van. Ha ugyanis egy lelkileg otthontalan ember sérült otthonosságát nem gyógyítjuk, nagy valószínúséggel még otthonteremtésre alkalmas fizikai helyhez jutva is nehézségei lesznek olyan módon kötôdni, hogy az számára valóban fizikai otthonná tudjon válni.

A lelki otthontalanság vizsgálatát és kezelését külön fontosnak tartjuk a fizikailag otthontalan (fedél nélküli, effektív hajléktalan, lakástalan és hajléktalanság veszélyében élô) emberek esetén, és mindenki másnál is, akinek jelen élethelyzetében vagy élete során korábban olyan meghatározó életeseményben volt része, amitôl az otthonossága, az otthon biztonságába vetett bizalma sérült. Fedél nélküli és effektív hajléktalan embereknél ez azért különösen indokolt, mert többségük nemcsak fizikailag, hanem lelkileg is otthontalan, és kutatási eredmények jelzik, hogy a fizikai otthonta- 
lanságból való kitalálásnak komoly akadálya lehet az, ha lelki otthontalanságát megfelelő terápiás eszközökkel nem kezeljük (pl. Dresser, 1985; Moore és mtsai, 1995; Riggs és Coyle, 2002; Toye, 2008; Bernstein és Foster, 2008).

A hajléktalanság veszélyében éló más lakástalan, illetve otthontalan emberek esetén a jelek szerint meglehetôsen elterjedt probléma a lelki otthontalanság. Az állami gondozott gyermekek, örökbe fogadott gyermekek, a rossz szociális helyzetú csövezó fiatal felnốttek, a pszichiátriai betegek, a helyveszteséget megélt emberek (pl. kilakoltatottak, háborúk, természeti katasztrófák áldozatai) és a családon belüli erôszak áldozatai mind-mind olyan populációk, amelyek a fizikai otthontalanságra súlyosan veszélyeztetettek. Ezzel párhuzamosan pedig, a felsorolt mindegyik csoport tagjai között nagyon gyakori, hogy az „otthon biztonságába”, a „valahova tartozásba” vetett bizalom súlyosan sérül, és így az érintett lelki otthontalanságban szenved. A hajléktalanság veszélyében élôk lelki otthontalanságának felismerése és megfelelô kezelése fontos védôfaktor lenne annak megelôzéséhez, hogy az érintettek ebbôl a szenzitív állapotból ne az otthontalanság, hanem az otthonosság (otthonteremtés, hazatalálás) irányába tudjanak elmozdulni. Végül, a lelki otthontalanság jelenségének felismerése fontos lehet tágabb kontextusban is, például olyan társadalmi, gazdasági, politikai változások, élethelyzetek (pl. költözés, válás, haláleset, lakásbetörés) esetén, amikor az otthonosság alapfokától függetlenül, akár döntôen megfelelô otthonélménnyel bíró emberek is átélhetnek otthontalanságot, és azt, hogy otthonuk stabilitásába vetett bizalmuk tartósan vagy átmenetileg sérül.

Tisztában vagyunk azzal, hogy nem egyszerú, ugyanakkor - a hajléktalanság tartós és hatékony kezelése érdekében - nélkülözhetetlen feladat az otthontalan emberek lelki állapotának kezeléséhez megfelelő anyagi, infrastrukturális és személyi feltételek biztosítása. Nagyon nehéz a lelki otthontalanságot kezelni egy tizen-huszonágyas hálóteremben, éjjeli menedékhelyen éjszakázó ember esetén vagy akár a közterületen egy kapualjban. A lelki otthontalanság felismerését és kezelését ennek ellenére, illetve ezzel együtt kiemelten fontosnak tartjuk.

\section{IRODALOM}

Altman, I., \& Rogoff, B. (1987). World Views in Psychology: Trait, Interactional, Organismic, and Transactional Perspectives. In D. Stokols, \& I. Altman (Eds), Handbook of Environmental Psychology (Vol. 1, pp. 7-40). New York: Wiley \& Sons.

American Psychological Association, Presidential Task Force on Psychology's Contribution to End Homelessness (2010). Helping People without Homes: The Role of Psychologists and Recommendations to Advance Research, Training, Practice, and Policy. Letöltve: 2016. 03. 14-én: http:// www.apa.org/pi/ses/resources/publications/end-homelessness.aspx

Amore, K., Baker, M., \& Howden-Chapman, P. (2011). The ETHOS Definition and Classification of Homelessness: An Analysis. European Journal of Homelessness, 5(2), 19-37.

Arce, A. A., \& Vergare, M. J. (1984). Identifying and Characterizing the Mentally Ill among the Homeless. In H. R. Lamb (Ed.), The Homeless Mentally Ill (pp. 75-89). Washington D. C: American Psychiatric Association.

Bandura, A. (1997). Self-Efficacy: The Exercise of Control. New York: Freeman/Times Books/Henry Holt \& Co. 
Barabásné Koller E. (2006). Az otthontalanság pszichológiai hatása a hajléktalan életmóddal kapcsolatba kerülố személyek identitásváltozásában. Mentálhigiéné és Pszichoszomatika, 7(4), 329-345.

Bényei Z., Gurály Z., Gyôri P., \& Mezei Gy. (2000). Tíz év után. Gyorsjelentés a fốvárosi hajléktalanokról - 1999. Esély, 2000(1), 62-95.

Berger, P. L., Berger, B., \& Kellner, H. (1974). The Homeless Mind: Modernization and Consciousness. New York: Vintage Books.

Bernstein, N., \& Foster, L. K. (2008). Voices from the Street: A Survey of Homeless Youth by Their Peers. California Research Bureau. Letöltve: 2016. 08. 30-án: https://www.library.ca.gov/ crb/08/08-004.pdf.

Boyce-Davies, C. (1994). Black Women, Writing and Identity: Migrations of the Subject. New York: Routledge.

Busch-Geertsema, V., Edgar, W., O’Sullivan, E., \& Pleace, N. (2010). Homelessness and Homeless Policies in Europe: Lessons from Research. A Report prepared for the European Concensus Conference on Homelessness, 9-10. December 2010. FEANTSA

Canter, D. (1977). The psychology of place. London: Architectural Press.

Cloke, P., May, J., \& Johnsen, S. (2010). Swept Up Lives? Re-Envisioning the Homeless City. Oxford: Wiley-Blackwell.

Dúll A. (1995). Az otthon környezetpszichológiai aspektusai. Magyar Pszichológiai Szemle, 35(5-6), $345-377$.

Dúll A. (1996). A helyidentitásról. Magyar Pszichológiai Szemle, 36(4-6), 363-391.

Dúll A. (2009). A környezetpszichológia alapkérdései. Helyek, tárgyak, viselkedés. Budapest: L'Harmattan.

Dúll A. (2012a). Az otthon dialektikája: a hétköznapi rutinok kreativitásától az otthon szakralitásáig. In Varga K., \& Gôsiné Greguss A. Cs. (Eds), Tudatállapotok, hipnózis, egymásra hangolódás (pp. 525-561). Budapest: L'Harmattan.

Dúll A. (2012b). Környezet-pszichológia-egészség. In Demetrovics Zs., Urbán R., Rigó A., \& Oláh A. (Eds), Az egészségpszichológia elmélete és alkalmazása I.: Személyiség, egészség, egészségfejlesztés (pp. 337-392). Budapest: ELTE Eötvös Kiadó.

Dúll A. (2015a). Amikor messze van az „odakinn” az „idebenn”-tôl: a helyváltoztatás és az identitás összefüggései. In Keszei A. (Ed.), Hely, identitás, emlékezet (pp. 19-33). Budapest: L'Harmattan.

Dúll A. (2015b). Az identitás környezetpszichológiai értelmezése: helyérzés, helykötôdés és helyidentitás. In P. Bodor (Ed.), Emlékezés, identitás, diszkurzus (pp. 79-99). Budapest: L'Harmattan.

Dresser, I. (1985). Psychological Homelessness: A Clinical Example. Journal of Social Work Practice, 1(4), 67-76.

Edgar, B. (2009). 2009 European Review of Statistics on Homelessness. Brussels: FEANTSA.

FEANTSA (2005). ETHOS - European Typology on Homelessness and Housing Exclusion. Brussels: FEANTSA, forrás: www.feantsa.org/code/en/pg.asp?Page=484, letöltve: 2018 . március 30.

Fitzpatrick, S. (2005). Explaining Homelessness: A Critical Realist Perspective. Housing, Theory and Society, 22(1), 1-17.

Gábor, Gy. (2007) Az otthon idegensége - az idegenbeliség otthonossága. Világosság, (11-12), 73-96.

Gale, J., Saftis, E., Márquez I. V., \& Espana B. S. (2008). A Psychological Treatment Programme for Traumatised Ex Military Personnel in the UK. Avances en Psicología Latinoamericana, 26(2), 119-134. 
Goodman, L., Saxe, L., \& Harvey, M. (1991). Homelessness as Psychological Trauma. American Psychologist, 46(11), 1219-1225.

Gyôri P. (1990). Gyorsjelentés a hajléktalanságról Magyarországon, 1990. In Andorka R., Kolosi T., \& Vukovich Gy. (Eds), Társadalmi riport (pp. 430-447). Budapest: Kolosi Tamás kiadása.

Gyôri, P. (2008). Fedél nélkül élốk. In Győri P., \& Vida J. (Eds), Az utcák népe (pp. 5-141). Budapest: Menhely Alapítvány és a Budapesti Módszertani és Szociális Központ és Intézményei.

Haber, M. \& Toro, P. A. (2004). Homelessness among families, children and adolescents: An ecological-developmental perspective. Clinical Child and Family Psychology Review, 7, 123-164.

Halpern, D. 1995. Mental Health and the Built Environment: More than Bricks and Mortar? London: Taylor \& Francis Ltd.

Hoksbergen, R. A. C. (1999). Psychic Homelessness. In G. J. M. Abbarno (Eds), The Ethics of Homelessness: Philosophical Perspectives (pp. 105-121). Amsterdam: Rodopi.

Hoksbergen, R. A. C., \& Laak, J. (2000). Adult Foreign Adoptees: Reactive Attachment Disorder May Grow into Psychic Homelessness. Journal of Social Distress and the Homeless, 9(4), 291-308.

Horvát M. T., Dúll A., \& László J. (2006). A helyveszteség vizsgálata migrációban lévô magyar fiatalok körében (kutatási beszámoló). In Dúll A., \& Szokolszky Á. (Eds), Környezet-pszichológia (pp. 133-153). Budapest: Akadémiai Kiadó.

Horvát M. T., Dúll A., \& László J. (2011). Helyvesztés-élmény és honvágy - egy „keserédes” jelenség környezetpszichológiája. Alkalmazott Pszichológia, 2, 21-32.

Iványi G. (1997). Hajléktalanok. Budapest: Sík Kiadó.

Kántor Á. (2005a). A hajléktalanság földrajza? A hajléktalan jelenség üzenetei. In Süli-Zakar I. (Ed.), „Tájak - Régiók - Települések...” (pp. 342-350). Debrecen: Didakt.

Kántor Á. (2005b). Egy gyökértelen állapot krizise, a „felnôttkori szociális újraközeledési krízis”. A hajléktalan állapotban lévố 30 és 60 év közti férfiak motivációs struktúrájának vizsgálata Jacqueline Royer Metamorfózisok tesztjével. Szakdolgozat (Témavezetô: Bakó T.). Budapest: KRE.

Kántor Á. (2007). A hajléktalan befogadása: a hajléktalan is én vagyok. Poszter. Illyés Sándor Emléknapok, 2007. március 19-21. Budapest: ELTE Pszichológiai Intézet.

Kántor Á. (2011). A hajléktalan emberek vágyai. Hajléktalan és nem hajléktalan férfiak motivációinak vizsgálata. Alkalmazott Pszichológia, 3, 46-63.

Kántor Á., \& Dúll A. (2013). A hajléktalan emberek otthonossági élményének vizsgálata. Elôadás. Magyar Pszichológiai Társaság XXII. Országos Tudományos Nagygyúlése. Kivonatkötet (pp. 196-197). Budapest: Magyar Pszichológiai Társaság.

Kántor Á., Brózik P., \& Dúll A. (2018). A hajléktalanság fizikai és lelki vonatkozásai. Kézirat.

Kennedy, R. (2014). The Psychic Home: Psychoanalysis, Consciousness and the Human Soul. London: Routledge.

Komáromi Éva (1994). A hajléktalanság mentálhigiénéje. Szenvedélybetegségek, 1(5), 381-390.

Lewin, K. (1972). A mezóelmélet a társadalomtudományban. Szerk. Mérei F. Budapest: Gondolat.

Mahler, M. S., Pine, F., \& Bergman, A. (1975). The Psychological Birth of the Human Infant: Symbiosis and Individuation. New York: Basic Books.

Marsh, A., \& Kennett, P. (1999). Exploring the New Terrain. In P. Kenneth, \& A. Marsh (Eds), Homelessness: Exploring the New Terrain (pp. 1-16). Bristol: Policy Press.

Melamed, S., Shalit-Kenig, D., Gelkopf, M., Lerner, A., \& Kodesh, A. (2005). Mental Homelessness: Locked Within, Locked Without. In A. Metteri, T. Kröger, \& A. Pohjola, (Eds), Social Work Visions from around the Globe: Citizens, Methods, and Approaches (pp. 209-226). New York: Routledge.

Milburn, N. G., Rice, E., Rotheram-Borus, M. J., Mallett, S., Rosenthal, D., Batterham, P., May, S., Witkin, A., \& Duan, N. (2009). Adolescents Exiting Homelessness over two Years: The Risk Amplification and Abatement Model. Journal of Research on Adolescence, 19, 762-785. 
Molnár, G. (1999). A hajléktalanok pszichés állapota. Mentálhigiéné és pszichoszomatika, 1(1-2), $38-44$.

Moore, J., Canter, D., Stockley, D., \& Drake, M. (1995). The Faces of Homelessness in London. London: Dartmouth.

Neale, J. (1997). Theorising Homelessness: Contemporary Sociological and Feminist Perspectives. In R. Burrows, N. Pleace, \& D. Quilgars (Eds), Homelessness and Social Policy (pp. 35-49). London: Routledge.

Ogden, T. (1986). The Matrix of the Mind: Object Relations and the Psychoanalytic Dialogue. Northvale, NJ: Jason Aronson.

Peled, A., \& Schwartz, H. (1999). Exploring the Ideal Home in Psychotherapy: Two Case Studies. Journal of Environmental Psychology, 19, 87-94.

Philippot, P., Lecocq, C., Sempoux, F., Nachtergael, H., \& Galand, B. (2007). Psychological Research on Homelessness in Western Europe: A Review from 1970 to 2001. Journal of Social Issues, 63(3), 483-504.

Pleace, N. (2000). The New Consensus, the Old Concensus and the Provision of Services for People Sleeping Rough. Housing Studies, 15, 58-94.

Proshansky, H. M., Fabian, A. K., \& Kaminoff, R. (1983). Place-Identity: Physical World Socialization of the Self. Journal of Environmental Psychology, 3, 57-83.

Riggs, E. H., \& Coyle, A. (2002). Young People's Accounts of Homelessness: A Case Study Analysis of Psychological Well-Being and Identity. Counselling Psychology Review, 17, 5-15.

Sallay V., \& Dúll A. (2006). „Érezd magad otthon!” Az otthonhoz fúződő viszony projektív, környezetpszichológiai szempontú vizsgálata. Magyar Pszichológiai Szemle, 61(1), 35-52.

Sallay V. (2008). Az önmagunkra találás helyei: környezeti önszabályozás elmélet és kutatás tükrében. Alkalmazott Pszichológia, 10(3-4), 145-161.

Seamon, D. 2000. Phenomenology in environment-behavior research. In S. Wapner, J. Demick, T. Yamamoto, \& H. Minami (Eds), Theoretical perspectives in environment-behavior research (pp. 157-178). New York: Plenum.

Study Group on Homelessness (1993). Homelessness - Report Prepared by the Study Group on Homelessness. Strasbourg: Council of Europe Press.

Tipple, G., Speak, S. (2005). Definitions of Homelessness in Developing Countries. Habitat International, 29(2), 337-352.

Toro, P. A., Trickett, E. J., Wall, D. D. \& Salem, D. A. (1991). Homelessness in the United States: An Ecological Perspective. American Psychologist, 46, 1208-1218.

Toro, P. A. (2007). Toward an International Understanding of Homelessness. Journal of Social Issues, 63(3), 461-481.

Toye, J. (2008). Emotionally Homeless. Therapy Today, 19(9), 26-30.

Udvarhelyi É. T. (2014). Az igazság az utcán hever: Válaszok a magyarországi lakhatási válságra. Budapest: Napvilág Kiadó.

Wardhaugh, J. (2012). Feminist Perspectives on Homelessness. In S. J. Smith (Ed.), International Encyclopedia of Housing and Home (pp. 163-171). Rotterdam: Elsevier.

Watson, S., \& Austerberry, H. (1986). Housing and Homelessness. A feminist perspective. London, Boston and Henley: Routledge and Kegan Paul.

Whitbeck, L. B., \& Hoyt, D. R. (1999). Nowhere to Grow: Homelessness and Runaway Adolescents and their Families. New York: Aldine de Gruyter. 


\title{
THE INVISIBLE FACE OF HOMELESSNESS: \\ THE PSYCHIC HOME AND THE PSYCHIC HOMELESSNESS
}

\author{
KÁNTOR, ÁRPÁD - DÚLL, ANDREA
}

Following a brief historical overview of the research on homelessness, we will present the key concepts of our approach. Subsequently we will introduce the best-known models aimed at understanding homelessness from a psychological viewpoint. After that we will summarize the literature on the less known phenomena of "psychic home" and "psychic homelessness", and we will introduce the theory of "psychic homelessness - psychic homeness continuum", which aims to group the physical and psychological aspects of homelessness and can be summarized as follows: 1. The "psychic home", the idea of our "home" in us (Kennedy, 2014), is an essential psychological structure that determines how one lives in the world and what emotions, attitudes etc. they have in connection with their socio-physical environment. 2. The development of the psychic home and the circumstances in which one feels at home are rooted in their childhood experiences of their own home, in the type of socio-physical environment they learned to move comfortably. If the idea of home develops in a maladaptive way in childhood or it is damaged later, the person will more or less become a psychic homeless and have difficulties with feeling at home in the world, in relationships, and with connecting to a physical place with home potential in a way that this connection serves as a basis for creating a physical home. 3. Not all physically homeless people are psychic homeless and not all psychic homeless people become physically homeless. 4. Total homelessness and total homeness are the two endpoints of a continuum with a wide range of intermediary states. This applies for both the physical and psychic state. 5. Similarly to physical homelessness, in psychic homelessness it is important to differentiate between chronic, situational or episodic homelessness. Taking the theory into account can be significant in the theoretical approach of homelessness and practical implementations as well.

Keywords: homelessness, the psychology of homelessness, psychic home, psychic homeness, psychic homelessness, environmental psychology 